\title{
研究報告
}

\section{除細動器付き植込み型心臓デバイスの新規植込み術を受けた 入院中の患者が社会復帰に向けて抱く不確かさ}

\author{
Uncertainty about the return to social life experienced \\ by inpatients after implantable cardioverter defibrillator placement \\ 鶴見幸代 ${ }^{1)}$ \\ Sachiyo Tsurumi \\ 中村美鈴 ${ }^{2)}$ \\ Misuzu Nakamura \\ 佐藤幹代 ${ }^{3)}$ \\ Mikiyo Sato
}

本研究は, 除細動器付き植込み型心臓デバイスの新規植込み術を受けた入院中の患者が退院前に社 会復帰に向けて抱く不確かさを明らかにすることを目的とした. デバイスの新規植込み術を受けた患 者 8 名を対象とし, 半構成的面接法で得たデータを Krippendorff の内容分析 (1980/1989) を参 考に分析をした. 不確かさは【デバイスとともに過ごす生活のイメージが湧かない】などの 10 の力 テゴリが抽出された. 不確かさには, 常にすべての不確かさの根底にあるデバイスを植え込んでもな お脅かされる生命に関連した不確かさと, 漠然とした社会復帰への不確かさ, 具体的な社会復帰への

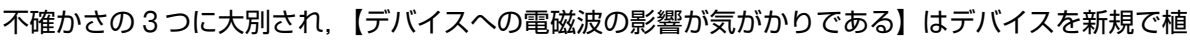
え込んだ入院中の患者に特徵的な不確かさと考察された. 社会復帰に向けて不確かさを抱く入院中の 患者への看護実践として, デバイスを植え込んだ患者同士のソーシャルサポートや, 信頼できる医療 者からの情報提供が不確かさの軽減に重要である可能性が示唆された.

キーワード : 植込み型除細動器, 両室ペーシング機能付き植込み型除細動器, 社会復帰, 不確かさ

Key Words : implantable cardioverter defibrillator (ICD), cardiac resynchronization therapy-defibrillator (CRT-D), return to social life, uncertainty

\section{I . 緒言}

2016 年の厚生労働省の調查（厚生労働省 2017）に よると，わが国の死因の第 2 位は心疾患であり，内訳 は心不全，虚血性心疾患，不整脈などであった，これ らの心疾患の非薬物療法として, 植込久型除細動器 (implantable cardioverter defibrillator; ICD), 両室ペーシ ング機能付き植込み型除細動器 (cardiac resynchronization therapy defibrillator；CRT-D）などの除細動器付き植込 み型心臟デバイスが近年発展して㧍り，今後わが国の 高齢化や心不全などの心疾患の増加 (日本循環器学会, 2019）とともに，さらなるデバイス植込み患者の増加
が予測される。

患者はデバイスを植え込むことで致死性不整脈によ る突然死を回避できるようになり，不整脈を止めてく れる安心感（山本ら，2002）を得ることができる。し かし，予測困難な除細動に起因した不安があり（山本 ら, 2002 /北村ら, 2003 /鈴木ら, 2012), デバイス 植え込み後に課せられた生活上のさまざまな制約に直 面するなかで，自分自身の身体感覚と課せられた制約 とが釣り合わないと感じている (中西ら, 2014)。また, デバイス植え込み前の患者は, 手術に抵抗があっても 致死性不整脈にはデバイスが不可欠であることから, 手術を受けるに至る状況がある (上谷ら，2015）。こ のように, デバイス植え込み患者は生命への安心感を 
得る一方で, 予測できない除細動に不安を抱き, 生活 上の制約やデバイス植え込みへの意思決定において, 明確な価值を割り当てて認識し, 今後の先行きを正確 に予測することが困難な状況にあると考えた。

Mishel（1988）は“病気の不確かさ”を「病気に関 連するさまざまな出来事に対してはっきりとした意味 を見出せない状態であり，それはある出来事について 十分な手がかりが得られないために，うまく構造化し たり分類したりできないときに生じる認知的状態であ り, 意思決定者が事象や出来事に明確な価値を割り当 てたり，ことの成り行きを正確に予測できないときに 起こる」と定義しており, 前述のデバイス植込み患者 の状況は Mishel（1988）の言う不確かな状況であると 考えた．とくに，デバイスを植え込む必要があると診 断され, 植え込みが行われる入院中は, 病気の認知や 植え込みへの意思決定などにおいて不確かな状況に陥 りやすいと考える. そのため, 患者が自分の状況を正 確に認識し, 今後の先行きが予測できるような看護実 践を早期から行う必要があると考えた. とりわけ, 新 規でデバイスを植え达む患者は, 社会復帰後に初めて デバイスとともに日常生活を送ることとなり, 不確か さを抱きやすいことが予測されるため, 入院中の不確 かさへの看護実践は重要と考える. しかし, 先行研究 で明らかになっている不確かさは, 概ね退院後の患者 を対象とした知見であり，入院中の不確かさを明らか にした研究は現時点ではほとんど見当たらない，その ため, 除細動器付き植込み型心臓デバイスを新規で植 え込んだ入院中の不確かさを明らかにし，その看護実 践への示唆を得る必要があると考える.

以上の背景より, 本研究の目的は, 除細動器付き植 込み型心臟デバイスの新規植込み術を受けた入院中の 患者が退院前に社会復帰に向けて抱く不確かさを明ら かにすることとした.

\section{II . 用語の定義}

社会復帰：デバイスの植え込みによる入院から, 再 び社会生活 [家庭生活・地域生活・職業生活・余㗇生 活（鈴木，2013）にに戻ることであり，入院前と同様 の社会生活のほかに, 入院前より業務量や時間などを 軽減した社会生活も含むとした。

不確かさ: Mishel の不確かさのオリジナル理論 (Mishel, 1988) は, 診断前は, または診断がついて
医学的治療を受けている急性期または慢性期の病気を 主な適応対象とし, 不確かさの認知から病前の安定し た状態を取り戻す適応へとつながるモデルである（野 川, 2009)。 そのため, 本研究の対象者である急性期 のデバイス植込み患者が社会復帰後の生活に適応しよ うとしながら抱く入院中の不確かさを明らかにするた めに適正な理論と考え，この理論を基盤とし，不確か さを入院中の患者が除細動器付き植込み型心臟デバイ スを植え込んだことによって社会復帰に向けて抱く不 安・気がかり・心配・困難とした。

\section{III. 研究方法}

\section{1. 研究デザイン}

除細動器付き植込み型心臓デバイスの新規植込み術 を受けた入院中の患者が社会復帰に向けて抱く不確か さを記述することによって，その不確かさを理解する ことを第一の目的（グレッグ, 2014）とし, 不確かさ を丹念に質的に探究し，それを記述していく方法であ る（野嶋，2008）質的記述的研究デザインとした.

\section{2. 研究対象者}

ICD または CRT-D の新規植込み術を行った 30 歳 以上の入院中の患者で, 言語的コミュニケーションが 可能であり, 主治医が心身ともに研究への参加が可能 であると判断した患者とした．また，退院後に入院前 と同様の社会復帰を予定しており, 研究の協力に同意 の得られた患者とし, 退院指導の前後で社会復帰への 不確かさが変化することを考慮し, 退院指導後の患者 で, 性別, 原疾患などの他の条件は問わないこととし た.

\section{3. 調査期間}

2017 年 $5 \sim 9$ 月

\section{4. 調查方法と內容}

1）半構成的面接法

面接ガイドを用いた半構成的面接法で, 病気やデバ イスについて気がかりなことはあるか，退院指導を受 けて気がかりな点や心配事はあるか，社会復帰に向け て気がかりな点や心配事はあるか, などの質問項目か ら, 患者が社会復帰に向けて抱く不確かさの情報を得 た. 


\section{2）診療記録}

患者の許可を得て, 診療記録から対象者の概要 (年 齢・性別・疾患名・デバイスの種類など）の情報を得 た。

\section{5. 分析方法}

Krippendorff（1980/1989）の内容分析は, データを 基にそこから文脈に関して再現可能でかつ妥当な推論 を行う調查のための 1 つの調査技法であり, メッセー ジを構造的にとらえ, メッセージの生じた文脈を重視 する必要性を定義している. そのため, 患者の発した 言葉を構造的にとらえ, 前後の文脈を重視して患者が 抱く不確かさを明らかにする本研究の目的に適正な分 析方法と考え，この方法を参考に以下の手順で分析を 行った.

\section{1）個別分析}

(1)面接を録音したデー夕を逐語録に起こし，フィー ルドノートと併せて何度も読み, 全体像を把握し た。

(2)意味内容を損なわないよう社会復帰に向けて抱 く不確かさを文脈単位で抽出した（一次コード）.

(3)意味の類似性に基づきコードを整理，分類し，高 次化することにより, 抽象度を上げた個人の不確 かさを抽出した（二次コード）.

\section{2) 全体分析}

個別分析で抽出した，個人の二次コードを合わせて 意味の類似性に基づき分類し, サブカテゴリ・カテゴ リを作成し，患者が社会復帰に向けて抱く不確かさに 即してサブカテゴリ・カテゴリを命名した.

\section{3）真実性, 妥当性の確保}

すべての分析過程において看護学研究者のスーパー バイズを受け, 複数の看護学研究者と確認しながら作 業を行い，真実性・妥当性を確保した.

\section{IV. 倫理的配慮}

著者の所属機関と調査施設の研究等倫理審査委員会 の承認を得て実施した.

対象者に, 研究趣旨や参加の自由意思, 途中辞退も 可能であること, 個人情報保護の方法などを説明した.
また，本研究により対象者個人には直接の利益はない が, 面接の時間的負担が生じるリスクや，面接が術後 であることや不確かさを想起することにより，万が一 ではあるが体調の変化が起こるリスクがあることを説 明した，さらに，対象者に体調の変化があった場合の 対応を，担当医師と病棟看護師に調整し，その旨も対 象者に説明した，以上の内容などを文章と口頭で説明 し同意を得た。

\section{V. 結果}

\section{1. 研究対象者の概要}

対象者は, 男性 6 名, 女性 2 名で, 平均年齢は $62.4 \pm 9.9$ 歳であった. 職業は, 男性 6 名は会社社長 や会社員，無職であり，女性 2 名は主婦であった。無 職以外の患者は, 社会復帰後も仕事や家事の軽減の可 能性はあるが，入院前の仕事や家事へ復㷌する予定で あった．無職の患者も，退院後は入院前と同様の社会 生活に復帰する予定であった，面接時の術後日数は, 1 名が 7 日目でほか 7 名は 6 日目であった。面接は 1 名につき 1 回で, 時間の合計は 549 分, 平均は 64 分土 10 分であった（表 1).

\section{2. 除細動器付き植込み型心臓デバイスの新規植 込み術を受けた入院中の患者が社会復帰に向 けて抱く不確かさ}

分析の結果, 個別分析では 525 の一次コード, 153 の二次コードが抽出され, 全体分析では 35 のサブカ テゴリ，10のカテゴリが抽出された（表 2). 以下， カテゴリを【】, サブカテゴリを〈〉, 患者の語りの 引用を斜体で示す。

\section{1）【予測できない死や不整脈への恐怖がある】}

〈今後の病状に対する不安がある〉〈突然死や予測で きない症状出現への恐怖がある〉などの 3 つのサブカ テゴリが含まれた。患者は, 病気による心機能の低下 や致死性不整脈を診断されたことによる今後の病状へ の不確かさを抱いていた，また，致死性不整脈による 意識消失の体験や予測できない致死性不整脈への恐怖 を感じ，再度不整脈が起きた際の死への恐怖や，病気 の悪化により長くは生きられないのではないかという 生命への不確かさがあった.

これ（デバイス）を入れたことにもよって,心臟（の 
表1 研究対象者の概要

\begin{tabular}{|c|c|c|c|c|c|c|c|c|}
\hline 研究対象者 & A & B & C & D & $E$ & $\mathrm{~F}$ & G & $\mathrm{H}$ \\
\hline 年齢 & 60 代 & 70 代 & 40 代 & 60 代 & 50 代 & 70 代 & 70 代 & 40 代 \\
\hline 性別 & 男性 & 女性 & 男性 & 男性 & 男性 & 男性 & 女性 & 男性 \\
\hline $\begin{array}{c}\text { 職業 } \\
(\text { 社会復帰後) }\end{array}$ & $\begin{array}{c}\text { 無職 } \\
\text { （デイ゙ービ } \\
\text { ス通所） }\end{array}$ & $\begin{array}{l}\text { 無職 } \\
\text { (主婦) }\end{array}$ & $\begin{array}{c}\text { 会社員 : 事務 } \\
\text { 職 } \\
\text { (同じ職場 } \\
\text { 復帰予定) }\end{array}$ & $\begin{array}{l}\text { 電気工事会社 } \\
\text { 社長 } \\
\text { (徐々に仕事 } \\
\text { を軽減する予 } \\
\text { 定) }\end{array}$ & $\begin{array}{c}\text { 会社員: 事務, } \\
\text { 物品管理 } \\
\text { (同じ職場 } \\
\text { 復帰予定) }\end{array}$ & 無職 & $\begin{array}{l}\text { 無職 } \\
\text { (主婦) }\end{array}$ & $\begin{array}{c}\text { 会社員 : 営業 } \\
\text { 職 } \\
\text { (同じ職場へ } \\
\text { 復帰予定) }\end{array}$ \\
\hline 疾患 & $\begin{array}{l}\text { 高血圧性心不 } \\
\text { 全 } \\
\text { 非持続性心室 } \\
\text { 頻拍 }\end{array}$ & $\begin{array}{l}\text { 拡張型心筋症 } \\
\text { 非持続性心室 } \\
\text { 頻拍 }\end{array}$ & $\begin{array}{l}\text { 萌大型心筋症 } \\
\text { 心室細動 }\end{array}$ & $\begin{array}{l}\text { 陳旧性心筋梗 } \\
\text { 塞による虚血 } \\
\text { 性心疾患に伴 } \\
\text { う心室細動 }\end{array}$ & $\begin{array}{l}\text { 虚血性心疾患 } \\
\text { (基礎心疾患 } \\
\text { 不明) } \\
\text { 心不全 }\end{array}$ & $\begin{array}{l}\text { 高血压 } \\
\text { 虚血性心疾患 } \\
\text { による慢性心 } \\
\text { 不全 }\end{array}$ & $\begin{array}{l}\text { 心サルコイ } \\
\text { ドーシス } \\
\text { 完全房室ブ } \\
\text { ロック } \\
\text { 心不全 }\end{array}$ & $\begin{array}{l}\text { 陳旧性心筋梗 } \\
\text { 塞 } \\
\text { 心室細動 }\end{array}$ \\
\hline $\begin{array}{c}\text { 手術前の } \\
\text { NYHA 分類 }\end{array}$ & III & П & I & П & IV & III & $\mathbb{I I} \sim \mathbb{N}$ & I \\
\hline $\begin{array}{l}\text { 一次予防 / } \\
\text { 二次予防 }\end{array}$ & 一次 & 一次 & 二次 & 二次 & 一次 & 一次 & 一次 & 二次 \\
\hline デバイスの種類 & CRT-D & ICD & ICD & ICD & CRT-D & CRT-D & CRT-D & ICD \\
\hline 術後日数 & 7 日目 & 6 日目 & 6 日目 & 6 日目 & 6 日目 & 6 日目 & 6 日目 & 6 日目 \\
\hline $\begin{array}{c}\text { インタビュー } \\
\text { 時間 }\end{array}$ & 48 分 39 秒 & 83 分 52 秒 & 78 分 & 67 分 56 秒 & 85 分 54 秒 & 61 分 29 秒 & 56 分 22 秒 & 67 分 32 秒 \\
\hline 家族構成 & $\begin{array}{l}\text { 独身で独居 } \\
\text { 姉 } 2 \text { 人が近所 } \\
\text { に住んでいる }\end{array}$ & $\begin{array}{l}\text { 息子が } 2 \text { 人い } \\
\text { るが } 1 \text { 人は要 } \\
\text { 介護で別居 } \\
\text { 1 人は同 }\end{array}$ & $\begin{array}{l}\text { 妻, 子ども } 2 \\
\text { 人と同居 }\end{array}$ & 妻と同居 & $\begin{array}{l}\text { 妻, 子ども } 1 \\
\text { 人と同居 }\end{array}$ & $\begin{array}{l}\text { 妻, 長男夫婦 } \\
\text { 之同居 } \\
\text { 娘 } 2 \text { 人は近く } \\
\text { に住んでいる }\end{array}$ & $\begin{array}{l}\text { 二世帯住宅で } \\
\text { 夫と長男, } \\
\text { 次男夫婦, 孫 } \\
\text { 之同居 }\end{array}$ & $\begin{array}{l}\text { 独身で独居 } \\
\text { 実家は遠方 }\end{array}$ \\
\hline
\end{tabular}

病気）っていうところもあるので（病気に対して） 不安なことは不安なんですが，具体的に何をどうすれ ばどうなっちゃうっていうのがよくわからなくて，も し何かあっても突然来るんだろうなっていう感覚があ るので $(C$ 氏 $)$.

\section{2【心臓やデバイスに影響のない生活スタイルへ の変更ができるのだろうか】}

〈病気が悪化しないが悪化しないために生活習慣を 改善することができるのだろうか〉〈身体に負担のな い生活スタイルへの変更ができるのだろうか〉などの 6つのサブカテゴリが含まれた. デバイスの植え込み により初めて心疾患を診断された患者や，慢性的に心 疾患がある患者など患者によって病気の認識はさまざ まであったが，いずれも植え込みをきっかけに，病気 の悪化や致死性不整脈の出現がないよう, セルフケア マネジメントが必要であることを実感していた，その ため, 退院後は心臟に負担がなく, デバイスへの影響
なども考慮した生活スタイルへ変更しなければならな いが，入院前の生活スタイルを変更し，適応していけ るのだろうかといった不確かさを抱いていた。

今のところは経過もいいっていうところもあって， 激しい運動とかこの間倒れたような体に負荷がかか るっていうものを自覚して抑えれば大丈夫なんじゃな いかなと思っているところですね，なんで，運動とか 走るのはちょっと控えなきゃいけないかなって思って いるところです ( $C$ 氏 $)$.

\section{3）【デバイスとともに過ごす生活のイメージが湧 かない】}

〈デバイスについてわからないことがある〉〈デバイ スに影響しない腕の可動制限がわからない〉などの 8 つのサブカテゴリが含まれた，患者には，病気やデバ イス，植え込み後の生活上の注意点などが記載された パンフレットが配布される。しかし，そこに記載され ている腕の可動制限やデバイスの電池交換, 未経験で 
表2 除細動器付き植込み型心臓デバイスの新規植込み術を受けた入院中の患者が社会復帰に向けて抱く不確かさ

\begin{tabular}{|c|c|}
\hline カテゴリ & サブカテゴリ \\
\hline 予測できない死や不整脈への恐怖がある & $\begin{array}{l}\text { 今後の病状に対する不安がある } \\
\text { 突然死や予測できない症状出現への恐怖がある } \\
\text { 不整脈出現への恐怖がある }\end{array}$ \\
\hline 心臓やデバイスに影響のない生活スタイルへの変更ができるのだろうか & $\begin{array}{l}\text { 病気が悪化しないために生活習慣を改善することができるのだろうか } \\
\text { ヘルスケアのためのセルフマネジメントについて不安がある } \\
\text { 身体に負担のない生活スタイルへの変更ができるのだろうか } \\
\text { 心臟に負担のない活動範囲はどの程度なのだろうか } \\
\text { 自分の会社の継続に関する心配がある } \\
\text { デバイスや身体への影響があるため趣味の継続が困難である }\end{array}$ \\
\hline デバイスとともに過ごす生活のイメージが湧かない & $\begin{array}{l}\text { デバイスについてわからないことがある } \\
\text { デバイスの電池や電池交換についての見通しがつかない } \\
\text { デバイスの作動に対するイメージが湧かない } \\
\text { 退院後の生活の予測が立たない } \\
\text { 創部の管理について心配がある } \\
\text { デバイスに影響しない腕の可動制限がわからない } \\
\text { パンフレットを読んでも日常生活の注意点に不安が残る } \\
\text { 睡眠時の体位がデバイスへの負担にならないか気がかりである }\end{array}$ \\
\hline 変容した自己イメージの受容ができるのだろうか & $\begin{array}{l}\text { デバイス植え込み部分の外見が気になる } \\
\text { 身体障害者になった自分をどのように受容していこうか }\end{array}$ \\
\hline デバイスへの電磁波の影響が気がかりである & $\begin{array}{l}\text { デバイスへの影響がない携帯電話の使用方法ができるのだろうか } \\
\text { IH の調理器具の電磁波の影響に関する不安がある } \\
\text { 家の中での電磁波の影響が気がかりである } \\
\text { 自動ドアや盗難防止センサーの電磁波の影響が気がかりである } \\
\text { 家の外での電磁波の影響が気がかりである } \\
\text { 就労に関連した電磁波の影響について心配がある }\end{array}$ \\
\hline 入院前と同様に仕事ができるのだろうか & $\begin{array}{l}\text { 職場復帰後に仕事内容の変更があるのではないだろうか } \\
\text { 職場復帰後の環境に身体的に耐えられるのだろうか }\end{array}$ \\
\hline $\begin{array}{c}\text { 自動車の運転ができなくななるため } \\
\text { 社会生活が不便になるのではないだろうか }\end{array}$ & $\begin{array}{l}\text { 自動車の運転ができなくなることで社会生活に支障が出る } \\
\text { 身体障害者制度で交通機関の利用ができるのだろうか }\end{array}$ \\
\hline 就労やソーシャルサポートに関連した金銭面での不安がある & $\begin{array}{l}\text { 就労に関連した金銭面での不安がある } \\
\text { ソーシャルサポートに関連した金銭面での不安がある }\end{array}$ \\
\hline 社会生活に関連したソーシャルサポートへの気がかりがある & $\begin{array}{l}\text { (生命·入院) 保険の加入や更新ができるのだろうか } \\
\text { 退院後に人的サポートが受けられるのだろうか }\end{array}$ \\
\hline 社会復帰後の人とのかかわりの変化に対応できるのだろうか & $\begin{array}{l}\text { 社会生活上の人とのかかわりにおいて気がかりがある } \\
\text { 家族や親戚とのかかわりに関して気がかりがある }\end{array}$ \\
\hline
\end{tabular}

ある除細動の感覚やその後の対応についてなど十分に 理解できない内容があるため, 社会復帰後にデバイス とともに過ごす生活のイメージを描くことが難しく， 漠然としたさまざまな生活上の不確かさを抱いてい た。
そうですね，(腕は）上まで (上げられない)，いつ まで動かしたらいけないのかはちょっとわからないん ですけど. (中略) でもあんまり上げないようにした ほうがね（いつまで腕を動かしてはいけないのか， パンフレットには）それは書いていないです。一応全 
部読んでみたんですけど（中略）たぶん葠ていると き(腕を) 上げているかどうかわかんないですけど. 外れたらどうしょうっていうのが,リード線が( $G$ 氏 $)$.

\section{4）【変容した自己イメージの受容ができるのだろ うか】}

〈デバイス植え込み部分の外見が気になる〉〈身体障 害者になった自分をどのように受容していこうか〉の 2つのサブカテゴリが含まれた，大きさも厚みもある 除細動器付き植込み型心臟デバイスを植え込むことに より, 前胸部に傷と膨らみが生じボディイメージが変 容する，そのため, 退院後に傷やデバイスが目立たな いような対策がとれるのかといった不確かさを抱いて いた．また，デバイスを植え込むことにより身体障害 者手帳を申請し社会的に身体障害者と認定されるた め, 他人から身体障害者だと認識されることや, 身体 障害者になった自分を受け入れていけるのかという不 確かさも抱いていた.

（デバイス植え込み部分の哆らみは気に）なります。 (中略)（デバイス植え込み部分の膨らみは）わかんな いですか？でもこっちのほう（デバイスが入ってい るほう）が膨らんでない？ そう？ 鏡見たらこっち のほうが㑷らんでいるような感じがする. (中略) そ ういうの(デバイスが目立たないような服装の工夫を) 考えないとね $(G$ 氏 $)$.

\section{5）【デバイスへの電磁波の影響が気がかりである】}

〈デバイスへの影響がない携带電話の使用方法がで きるのだろうか〉〈IH の調理器具の電磁波の影響に関 する不安がある〉などの 6 つのサブカテゴリが含まれ た.また，このカテゴリは 7 名の患者の語りから得ら れたカテゴリであり, 本研究においてもっとも多くの 患者が共通して抱く不確かさであった。臟デバイス を植え込む患者は, デバイスへの電磁干渉に注意が必 要であり, 患者に配布されるパンフレットでも具体的 な注意が記載されている，日常生活上で患者が使用し たり近づいたりする物も多く記載されており, 新規で デバイスを植え込んだ患者はどんなものがどの程度デ バイスに影響し，影響した場合どのような状況になる のかといった予測の立たない不確かさを抱いていた。

あと細かいところでは，携带を胸ポケットに入れて いたんですけど，今度はズボンのポケッケットの中な のか，どっかなのか…（中略）右で通話を（するよ
うにとパンフレットに書いてあった)。(携帯電話がデ バイスに）近づくと誤作動しちゃうんですかね，それ とも機械が変な設定になっちゃうんですが ( $C$ 氏).

\section{6）【入院前と同様に仕事ができるのだろうか】}

〈職場復帰後に仕事内容の変更があるのではないだ ろうか〉職場復帰後の環境に身体的に耐えられるの だろうか〉の 2 つサブカテゴリが含まれた，患者は デバイスを植込み身体障害者となったことにより，雇 用形態の変更や部署異動があるのではないかという不 確かさを抱いていた．また，デバイス植え込みにより 入院前よりも身体的に無理ができないことを感じ, 仕 事に身体がどの程度耐えられどの程度耐えられるのか という不確かさや, 仕事内容や仕事量の軽減をしなが ら仕事を継続していけるのかという不確かさを抱いて いた.

困るのは，これ（デバイス）を入れると今度身体障 害者になっちゃうんですよね，そうすっと，勤務の あれが決められちゃうから，残業やっちゃダメ，休出 (休日出勤) やっちゃダメ, 重筋労働はやっちゃダメっ つーと, 決められた仕事になっちゃうからそこらへん かな $(E$ 氏).

\section{7）【自動車の運転ができなくなるため社会生活が 不便になるのではないだろうか】}

〈自動車の運転ができなくなることで日常生活に支 障が出る〉〈身体障害者制度で交通機関の利用ができ

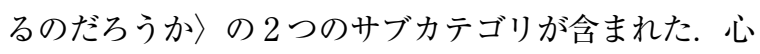
臓デバイス植え込み後の自動車の運転は, 道路交通法 および警察庁交通局運転免許課長通達により規定され ている，患者は，自動車の運転ができなくなることに よる日常生活の交通手段変更への不確かさを感じてい た。また，その対策として身体障害者制度を活用した 交通機関の利用を考えていたが，身体障害者制度に関 する情報も不十分であり, どの程度サポートが受けら れるのかという不確かさも感じていた。

通院っていうか，もう車でかみさんの運転で来るし かないからね，結構こっち(デバイスを植え达んだ病 院）に来るのも不便なんですよね，A市からだとね。 2 回くらい乗り換えるのかな, 電車も ( $D$ 氏). 


\section{8）【就労やソーシャルサポートに関連した金銭面 での不安がある】}

〈就労に関連した金銭面での不安がある〉〈ソーシャ ルサポートに関連した金銭面での不安がある〉の $2 つ$ のサブカテゴリが含まれた，入院生活のため休職して いる患者が多く, 今後の就労復帰の不確かさに伴う収 入面での心配があり, 就労に関連した金銭面での不確 かさを抱いていた．また，デバイスの治療費が高額で あるため, 入院費の支払いでどの程度が健康保険適応 となるのか, 高額療養費制度の支払額はどの程度かな どの金銭面での不確かさも抱いていた，さらに，退院 後の生活の身体障害者年金の受給制度などのソーシャ ルサポートについても十分な情報が得られず，金銭的 に入院前と同様の社会生活が送れるのかという不確か さも抱いていた.

(仕事より)抒金のほうが心配ですね，傷病手当てが， ここがネックで，(中略）結局普通の給料がもらえる ときに，やっと傷病手当が入るくらいだから．(中略） 年金のほうももらうまでは結構手続き上難しいし，時 間もかかるんで $(H$ 氏 $)$.

\section{9）【社会生活に関連したソーシャルサポートへの 気がかりがある】}

〈(生命・入院 $)$ 保険の加入や更新ができるのだろう か〉〈退院後に人的サポートが受けられるのだろうか〉 の 2 つのサブカテゴリが含まれた，患者の中には, 新 たに致死性不整脈と診断されたため, 今後の（生命 · 入院）保険の加入や更新への不確かさを抱く患者がい たままた，゙゙バイスを植え达んだことや病気に伴う活 動制限や自動車の運転制限, 就労などの退院後の社会 生活を支援してくれる人的ソーシャルサポートについ ての不確かさを抱いていた.

例えば生命保険とか，(デバイスが入っていること が）今後の制約になっちゃうので（中略）いずれ例 えばがんになったとかそういう, 介護が必要だとか骨 折して動けないだとか，そういったこの病気以外に起 こったときの不安というか，保険的な安心の面も含め て準備不足な面もあって, これだけ（今の病気と機械） だったらね，いいんだけど，今後っていうとそういっ た，保険がらみの不安は残っていますね。（中略）きっ と更新とか難しいかなと思って $(C$ 氏 $)$.

\section{0【社会復帰後の人とのかかわりの変化に対応 できるのだろうか】}

〈社会生活上の人とのかかわりにおいて気がかりが ある〉〈家族や親戚とのかかわりに関して気がかりが

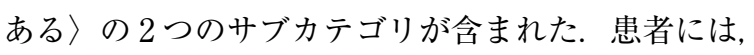
デバイスを植え込むことによって, 社会生活上の他人 とのかかわりにおいてデバイスを植え込んだことを言 わなければ不都合が生じる場面があるかもしれないと いう不確かさがあった．また，家族や親戚とのかかわ りでもデバイスを植え达んだことにより心配をかける のではないかといった, 社会生活上の人とのかかわり に扒いて不確かさを抱いていた.

床屋なんかいつも肩もむもんね。こっちまで（植え 込み部分まで）触られたらすぐわかっちゃうじゃん， (デバイスが入っていることは) 言わないわけにはい かないしさ。いや，肩（はもまなくて）いいよって言 うかもしれないけど，高の前にやられちゃう可能性も あるしさ，そこで, 何だこれって, 向こうはビビっちゃ うかもしんないし，こっちは痛いかもしんないし（E 氏).

\section{VI. 考察}

\section{1. 除細動器付き植込み型心臓デバイスの新規植 込み術を受けた入院中の患者が社会復帰に向 けて抱く不確かさ}

10 の不確かさのカテゴリをサブカテゴリの内容も 含めて検討した結果, 入院中に社会復帰に向けて抱く 不確かさは，デバイスを植え込んでもなお脅かされる 生命に関連した不確かさ, 漠然とした社会復帰への不 確かさ, 具体的な社会復帰への不確かさ, の3つに大 別されると考えた.

漠然とした社会復帰への不確かさと具体的な社会復 㷌への不確かさには,【心臟やデバイスに影響のない 生活スタイルへの変更ができるのだろうか】や【デバ イスへの電磁波の影響が気がかりである】などの心疾 患や命を預けるデバイスに起因した，生命に関連した 不確かさの内容が含まれていた。 このことから，デバ イスを新規で植え达んだ入院中の患者において，デバ イスを植え込んでもな招劦かされる生命に関連した不 確かさは常に他の 2 つ不確かさの根底にあると考え た.

また，具体的な社会復帰への不確かさの【デバイス 


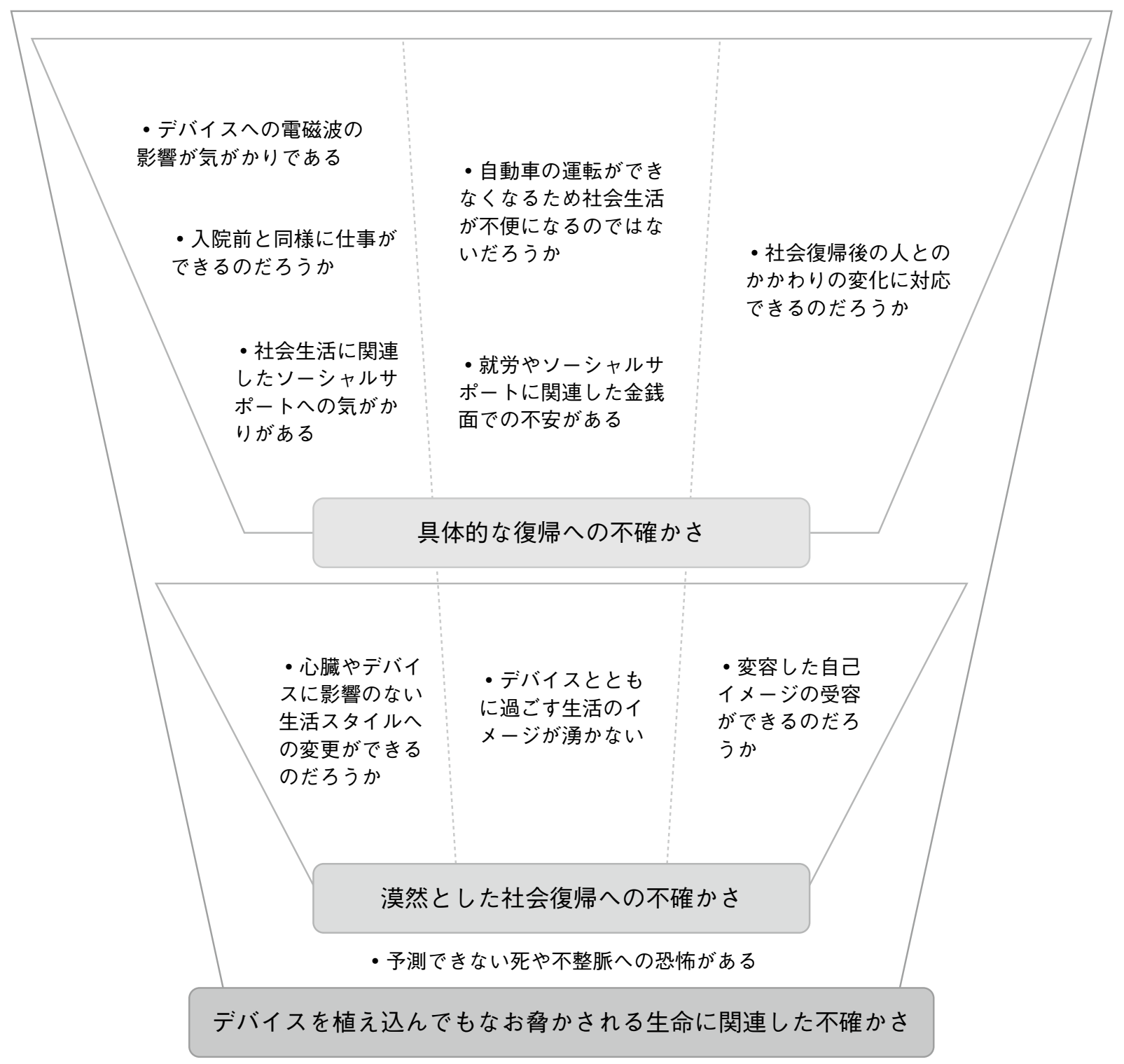

図1 除細動器付き植込み型心臓デバイスの新規植込み術を受けた入院中の患者が社会復帰に向けて抱く不確かさ

への電磁波の影響が気がかりである】や【入院前と同 様に仕事ができるのだろうか】などのカテゴリは,〈IH の調理器具の電磁波の影響に関する不安がある〉や〈職 場復帰後に仕事内容の変更があるのではないだろう か〉などの社会復帰後の生活スタイルの変更に関連し た具体的な不確かさであり, 漠然とした社会復帰への 不確かさの【心藏やデバイスに影響のない生活ス夕イ ルへの変更ができるのだろうか】のカテゴリに関連が あると考えた. 同様に, 漠然とした社会復帰への不確 かさの【デバイスとともに過ごす生活のイメージが湧 かない】と【変容した自己イメージの受容ができるの
だろうか】に関連があると考えた具体的な社会復帰へ の不確かさを分類した.

以上のように 10 のカテゴリ間の関連性を検討し, 図式化した（図 1).

\section{1）デバイスを植え込んでもなお脅かされる生命 に関連した不確かさ}

この不確かさは，【予測できない死や不整脈への恐 怖がある】のカテゴリが含まれると考えた．患者は， デバイスの植え込みにより, 致死性不整脈による生命 の危機的状況からは逃れることができたが，不整脈は 
デバイスの植え込みによって完治するわけではないた め, 突然の不整脈の出現や心疾患により長くは生きら れないのではないかといったデバイスを植え込んでも な抄劦かされる生命に関連した不確かさを抱いている と考えた.

器質的心疾患をもち, 致死性不整脈の頻度が高い患 者はデバイスを植え込むことで安心が得られ，快適・ 活動性が高まる傾向にある（山本ら，2002）。これは， デバイスによって心疾患症状の緩和がみられたり, 致 死性不整脈時に作動が起きたりすることで, デバイス に生命が守られているという安心感が生じるためと考 える. しかし, 本研究の患者は, 半数が致死性不整脈 の経験がなく, 半数が心不全などの自覚症状がなかっ た。また, 入院中にデバイスが作動した患者は抢らず, 面接の時点ではデバイスの作動チェックも行っていな かった. これらのことより, 心疾患症状の緩和や不整 脈出現時にデバイスによって守られるなどの実感が少 なく, デバイス植え込み後も病気や生命に対する先行 きの見えない不確かさを抱いていたと考える.

\section{2）漠然とした社会復帰への不確かさ}

この不確かさは, 【心臟やデバイスに影響のない生 活スタイルへの変更ができるのだろうか】【゙゙バイス とともに過ごす生活のイメージが涌かない】などの, デバイスとともに過ごす社会復帰後の生活のイメージ が不鮮明であるであることに関連した 3 つのテゴリ が含まれると考えた. デバイスの植込み患者は, 療養 生活において日常生活の再構築に関心があり(齊藤ら, 2009），自己管理を模索していた（梅田・井上，2012） とされている. 本研究の患者は, 新規の植え込みであ るためデバイスに関するさまざまな知識を修得して退 院する必要があるが，パンフレットには一般的な内容 が記載されているのみで, 個別に対応できるような具 体的な事柄は記載されていない，そのため, 退院後の 個別の生活を具体的にイメージすることが難しく, 【 臓やデバイスに影響のない生活スタイルへの変更がで きるのだろうか】【゙バイスとともに過ごす生活のイ メージが湧かない】変容した自己イメージの受容が できるのだろうか】などのように, 漠然と社会復帰へ の不確かさを抱いていたと考える.

\section{3）具体的な社会復帰への不確かさ}

この不確かさは,【デバイスへの電磁波の影響が気
がかりである】【院前と同様に仕事ができるのだろ うか】などの, 患者それぞれの社会復㷌後の生活をイ メージした際に抱くより具体的な内容の 6 つのカテゴ リが含まれると考えた，患者は，デバイスの植込み術 後から, 看護師と共に本格的に病気やデバイス, 社会 復帰後の生活についての知識を修得していく．これら の不確かさは，デバイスに関連したさまざまな知識を 自らの退院後の生活に照らし合わせて考えることがで きた際に抱く不確かさと考えた。

【入院前と同様に仕事ができるのだろうか】や【就 労やソーシャルサポートに関連した金銭面での不安が ある】の仕事に関連したカテゴリについて，黒田ら （2013）の退院後の患者を対象とした先行研究では, 対象者の約半数が働く世代と考えられる $20 \sim 59$ 歳で あったが，財政面での問題を心配していたのは約 16\%のみであった．デバイスを植え込んでからの期間 は 1 年未満〜 10 年未満と広範囲であり退院後の期間 は特定できないが, この先行研究より金銭面での不確 かさは社会復帰後に仕事を再開することで軽減される 可能性も考えられる.

【デバイスへの電磁波の影響が気がかりである】の カテゴリは 7 名の患者が含まれたカテゴリであり, 本 研究で明らかになった不確かさの中でもっとも多くの 患者が抱く不確かさであった，デバイスを植え込んだ 患者に関連した先行研究では, 本研究の結果と同様に 病気や不整脈, 生活スタイルの変更, 仕事や金銭面, 自動車の運転, ソーシャルサポートなどに関連した不 安や気がかりを明らかにした研究が散見される。しか し, 電磁干渉に関連した先行研究は, デバイスの植え 込火後に盗難防止装置店への出入りに対する生活の不 満がある（山本ら，2002）や，電磁波はどの程度影響 するのかという療養生活上の関心がある（齊藤ら， 2009), など比較的知見が少なかった. 本研究で他の 不確かさに比べて電磁波に関連した不確かさがより多 く抽出された理由としては, 対象者がデバイスととも に過ごす社会生活が未経験の入院中の新規の植え込み 患者であったためと考える. 多くの先行研究では対象 者が退院後の患者であり, デバイスとともに生活を送 るなかで日常生活上はそれほど電磁波を気にせずに生 活できることを実感していたため, 電磁干渉に関連し た不確かさが少ないと考えた．以上の理由から，【デ バイスへの電磁波の影響が気がかりである】はデバイ スを新規で植え込んだ入院中の患者にもっとも多く語 
られた特徵的な不確かさと考える。

\section{2. 除細動器付き植込み型心臓デバイスの新規植 込み術を受けた入院中の患者が社会復帰に向 けて抱く不確かさに対する看護実践への示唆}

【予測できない死や不整脈への恐怖がある】という デバイスを植え込んでもな抄かされる生命に関連し た不確かさの要因は, 新規のデバイス植え込みである ことや, 病気や致死性不整脈, デバイスに関しての知 識や情報, 経験にそしく, デバイスからの恩恵を実感 していないことなどであると考えた．患者には〈今後 の病状に対する不安がある〉や，〈不整脈出現への恐 怖がある〉ため, 病気やデバイスに関連した知識や情 報の提供が重要と考える. また, サポートグループは ストレスと不安を軽減し, 患者の知識を向上させ, メ ンバーが経験を共有して比較できるようなポジティブ な雰囲気の構築を促進する (Dickerson et al, 2000). デバイスを植え込んで社会生活を送る患者の経験談を 聞くことによりデバイスのメリットや病気とともに生 きる今後の社会生活のイメージが湧き，〈突然死や予 測できない症状出現への恐怖がある〉などの不確かさ が軽減されると考える。このようなソーシャルサポー 卜は，情報提供以外にも各メンバーがさまざまな危機 的出来事に対処するための人脈となり, 不確かさの軽 減に役立つ（Mishel, 1988）とされている．そのため, 入院中に患者会などの情報提供をし, 患者同士で病気 や療養生活について語り合うことは，それぞれの体験 を共有し不確かさをポジティブにとらえ, 不確かさを 軽減するために重要と考える.

また，患者は【心臟やデバイスに影響のない生活ス タイルへの変更ができるのだろうか】【デバイスとと もに過ごす生活のイメージが湧かない】という漠然と した社会復帰への不確かさを抱いていた。 デバイス植 込み患者と同様の心疾患である経皮的冠動脈インター ベンションを受けた心筋梗塞患者にも, 退院直前から 社会復帰を遂げる時期にかけて「今後の生活の見通し の立たなさ」という不確かさが生じていた（武田ら， 2010). しかし，患者は入院中に医療者に相談したり， 退院後は就労時間を少しずつ延長して慣らしていくこ とで社会復帰を徐々に進め, 生活を獲得しており, こ の不確かさは社会復帰を遂げ日常生活に戻るなかで, 徐々に解消された（武田ら，2010）。また，退院後の 患者では, 基本的な生活行動のうち, 睡眠, 食欲, 入
浴, 趣味については, デバイスを植え込む前とほぼ変 化がない（西村ら，2006）ことがわかっている. 以上 の先行研究の知見より, デバイスを植え达んでも基本 的な日常生活行動は大きく変化しない可能性があり, 【心臓やデバイスに影響のない生活スタイルへの変更 ができるのだろうか】や【デバイスとともに過ごす生 活のイメージが湧かない】といった見通しの立たない 漠然とした内容の不確かさは社会復帰とともに徐々に 軽減すると考えられる。 そのため, 実際に社会生活を 送ることで徐々にデバイスとともに過ごす生活に慣れ ていくことや，それほど大きな生活の変化はないと考 えられることなどの情報提供が重要と考える.

本研究では, デバイスを新規で植え込んだ入院中の 患者にもっとも多く語られた特徵的な不確かさは【デ バイスへの電磁波の影響が気がかりである】ことが明 らかになった，電磁干渉に関連した先行研究は, 盗難 防止装置設置店への出入りに関連した不満（山本ら， 2002）や電気製品に関連した ICD への不安（北村, 2003）などの報告にとどまり比較的少数であったこと から, この不確かさは退院後に社会生活を経験するこ とで徐々に軽減すると考えた，実際には，日常生活環 境による電磁干渉が健康被害を引き起こすことはまれ であり，その多くは可逆的なものである（河野，2016） ため, 患者個人の社会生活に合わせて, 電磁干渉とな る原因やその対策などの正確な情報を提供し，必要以 上に不安にならないような情報提供が重要である。

デバイスを植え込んだ患者の $45.2 \%$ 「医師や看護 師ともっとコミュニケーションがとりたい」と回答し, 状態不安の高い患者でこの回答の割合が高いことが報 告（黒田ら，2013）されている. 本研究の患者のよう に, 退院後の社会復帰に対してさまざまな不確かさを 抱いている患者は入院中の不安が強く, 情報収集や精 神的サポートのために医療者とのコミュニケーション を望んでいると推察される．信頼できる医療者は不確 かさに影響を与え軽減することができる (Mishel, 1988）とされているため, 良好なコミュニケーション と信頼関係の構築に努め, 除細動器付き植込み型心臓 デバイス植込み術後の社会復帰に向けては, 患者の入 院中にできるかぎり不確かさを軽減する看護実践が重 要である可能性が示唆された. 


\section{VII. 結論}

1. 除細動器付き植込み型心臟デバイスの新規植込み 術を受けた入院中の患者が社会復帰に向けて抱く 不確かさとして，【予測できない死や不整脈への恐 怖がある】心臓やデバイスに影響のない生活ス夕

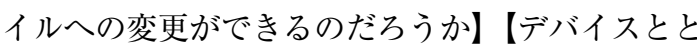
もに過ごす生活のイメージが湧かない】変容した 自己イメージの受容ができるのだろうか】【デバイ スへの電磁波の影響が気がかりである】入院前と 同様に仕事ができるのだろうか】【自動車の運転が できなくなるため社会生活が不便になるのではな いだろうか】【就労やソーシャルサポートに関連し た金銭やソーシャルサポートに関連した金銭面で の不安がある】【社会生活に関連したソーシャルサ ポートへの気がかりがある】【社会復帰後の人との かかわりの変化に対応できるのだろうか】の 10 の カテゴリが明らかになった。

2. 除細動器付き植込み型心臟デバイスの新規植込み 術を受けた入院中の患者が社会復帰に向けて抱く 不確かさは，常にすべての不確かさの根底にある デバイスを植え込んでもな抄かされる䅉命に関 連した不確かさと, 漠然とした社会復帰への不確 かさ，具体的な社会復帰への不確かさの 3 つに大 別され，【デバイスへの電磁波の影響が気がかりで ある】はデバイスを新規で植え込んだ入院中の患 者に特徵的な不確かさと考察された。

3. 除細動器付き植込み型心臟デバイスの新規植込み 術を受けた入院中の患者が社会復帰に向けて抱く 不確かさへの看護実践として，デバイスを植え込 んだ患者同士のソーシャルサポートや信頼できる 医療者からの情報提供が，不確かさの軽減に重要 である可能性が示唆された。

\section{VIII. 研究の限界と今後の課題}

面接は対象者 1 人につき 1 回, 時間は平均約 60 分 と限られていたため, 不確かさを十分に語ることがで きなかった可能性がある。また，対象施設が 1 施設の み，対象者は背景がさまざまな 8 名であったため, 除
細動器付き植込み型心臟デバイスの新規植込み患者全 般の知見とするには，結果の一般化に限界がある.

本研究ではデバイスの新規植込み術を受けた患者が 入院中に抱く不確かさが明らかとなった．今後は不確 かさへの看護介入を行い，デバイスの新規植込み術を 受けた患者への入院中のより具体的な看護実践の効果 を明らかにすることが課題と考える。

\section{謝辞}

研究に快くご協力いただきました患者の皆様，また，研究 にご理解とご協力をいただきました対象施設の皆様に深く感 謝申し上げます，なお，本研究は修士論文に加筆修正を加え たものであり，学術集会において一部発表したものである.

\section{利益相反}

本研究における利益相反は存在しない.

\section{文献}

Dickerson SS, Flaig DM, Kennedy MC. (2000). Therapeutic connection: Help seeking on the Internet for persons with implantable cardioverter defibrillators. Heart Lung, 29, 248-255.

グレッグ美鈴 (2014)．主な質的研究と研究手法. グレッグ美 鈴，麻原きょみ，横山美江(編著)，よくわかる質的研究 の進め方・まとめ方一看護研究のエキスパートを目指し て. 54-72, 東京：医歯薬出版.

北村麻理, 友成恵子, 平林淳子 (2003)。植元込み型除細動器 植え込み患者の不安に対する集団アプローチの効果. 日 本看護学会論文集：成人看護 II，33，30-32.

河野律子 (2016)。 心臓デバイス治療と社会生活 (自動車運転 · 電磁干渉)。心臓, 48, 1014-1019

厚生労働省 (2017)，第6表 性別にみた死因順位(第10位まで) 別死亡数 - 死亡率 (人口10万対) - 構成割合. Retrieved from : https://www.mhlw.go.jp/toukei/saikin/hw/jinkou/ kakutei16/d1/10_h6.pdf(閲覧日：2017年11月26日)

Krippendorff K. (1980)／三上俊治, 椎野信雄, 橋元良明 (1989). メッセージ分析の技法一「内容分析」への招待．東京：勁 草書房.

黑田裕美, 楠葉洋子, 久田瞳, 他 (2013)。ICD患者の生活活 動や考え方の実態と不安との関連. 日本循環器看護学会 誌, 8(2), 47-54.

Mishel MH. (1988). Uncertainty in illness. Image J Nurs Sch, 20, 225-232.

中西啓介, 岡美智代, 富田威 (2014)。植込み型除細動器 (ICD)を移植した壮年期患者がICD とともにいきるプロ 七ス，日本看護科学会誌，34，311-320.

日本循環器学会 (2019)。2017年 (2018年度害施・公表) 循環器 疾患診療実態調査報告書Web版. Retrieved from : http:// www.j-circ.or.jp/jittai_chosa/jittai_chosa2017web.pdf(閲覧日 : 2019年09月07日） 
西村典子, 宮田美智子, 寺瀬真利子, 他 (2006)，植え込み型 除細動器植え込み患者の退院後の生活状況調查. 日本看 護学会論文集：成人看護 I , 37, 79-81.

野川道子 (2009). Mishelの病気の不確かさ理論。佐藤栄子(編 著), 中範囲理論入門一事例を通してやさしく学ぶ. 343359 , 東京 : 日総研出版.

野嶋佐由美(2008)。研究デザイン。南裕子(編), 看護におけ る研究. 66-105, 東京：日本 看護協会出版会.

齊藤奈緒, 多留ちえみ, 吉田明弘, 他 (2009). ICD 植込み患 者の療養生活上の関心に関する検討一日常生活活動の調 整を中心とした教育的支援にむけて。臓リハビリテー ション, 14, 139-144.

鈴木千尋，村上奈保子，高橋陽子，他 (2012)。ICD 植え込み 術後の患者が退院後に抱える問題点一電話訪問の結果か ら. 北海道社会保険病院紀要, 12, 12-15.

鈴木純恵 (2013). 成人にとってのセルフケア再獲得一七ルフ
ケアの低下した大人の理解と支援の視座. 安酸史子, 鈴 木純恵, 吉田澄恵(編), 成人看護学 (3) セルフケアの再獲 得. ナーシング・グラフィカ, 第2版, $12-20$, 東京: メ ディカ出版

武田真弓, 旗持知恵子, 松下由美子(2010). 経皮的冠動脈 ンターベンションを受けた心筋梗塞患者の回復過程にお ける「不確かさ」一フォローアップ心臓カテーテル検查 期間に焦点をあてて．日本慢性看護学会誌，4(2)，33-40.

上谷千夏，瀬戸奈津子，谷本真理子，他 (2015)。 日本に打け る植込み型除細動器治療選択の意思決定支援に関する文 献検討. 日本慢性看護学会誌, 9(2), 67-73.

梅田亜矢, 井上智子 (2012)。植込み型心臟機器の遠隔モニ夕 リングを受ける患者の療養生活と看護支援の検討，お茶 の水看護学雑誌, $7(1), 30-41$.

山本志織, 細川友恵, 河原尚美, 他 (2002)。植え込み型除細 動器植え込み患者の退院後のQOL の実態. 日本看護学会 論文集：成人看護 II，33，33-35.

\begin{abstract}
This study examined the uncertainty about the return to social life experienced by inpatients, who have undergone implantable cardioverter defibrillator (ICD) placement, before discharge. Semi-structured interviews were conducted with 8 patients after ICD placement, and the obtained data were analyzed, on the basis of Krippendorff's content analysis method. The patients' uncertainty was explained by 10 categories, including [difficulty in coping with how my life will be with ICD]. They were also classified into 3 types: 1) general uncertainty about their lives, which remained at risk even after ICD placement a basis of uncertainty at all times, 2) vague uncertainty about the return to social life and 3) uncertainty about practical aspects of the return [Worry about the influences of electromagnetic waves on ICD] may represent uncertainty specific to inpatients after ICD placement. When performing nursing practice for in patients with uncertainty about the return to social life, it may be important to promote social peer support among them and provide information by reliable medical professionals, in order to reduce such uncertainty.
\end{abstract}

